\author{
Alicja DĄBROWSKA, Robert GIEL, \\ Sylwia WERBIŃSKA-WOJCIECHOWSKA \\ Wrocław University of Science and Technology (Politechnika Wroctawska)
}

\title{
HUMAN SAFETY IN AUTONOMOUS TRANSPORT SYSTEMS - REVIEW AND CASE STUDY
}

\section{Bezpieczeństwo czlowieka w autonomicznych systemach transportowych - przegląd literatury i studium przypadku}

\begin{abstract}
During the robot's operational tasks, a key issue is its reliability in the aspect of human safety providing. Currently, there are a number of methods used to detect people, and their selection most often depends on the type of process carried out by robots. Therefore, the article is focused on the development of a comparative analysis of selected methods of human detection in the storage area. The main aspect in the context of which these systems were compared concerned the safety of robotic systems in the space of human occurrence. Main advantages and drawbacks of the methods in various applications were presented. The detailed analysis of the achievements in this area gives the possibility to identify research gaps and possible future research directions when using these tools in autonomous warehouses designing processes.
\end{abstract}

Keywords: object detection system, safety, human detection, autonomous transport, warehouse, review

\begin{abstract}
Streszczenie: Podczas wykonywania zadań operacyjnych przez robota, kluczowym zagadnieniem jest jego niezawodność w aspekcie bezpieczeństwa człowieka. Opracowano szereg metod służacych do wykrywania człowieka, a ich wybór najczęściej uzależniony jest od rodzaju procesu realizowanego przez roboty. W zwiazku z tym, celem artykułu jest przeprowadzenie analizy porównawczej wybranych metod wykrywania człowieka w strefie magazynowej. Główny aspekt, w kontekście którego dokonano porównania tych systemów dotyczyt bezpieczeństwa pracy systemów robotycznych wprzestrzeni wystepowania człowieka. Wskazano główne zalety $i$ wady wybranych metod $w$ różnych zastosowaniach. Szczegółowa analiza osiagnięć $w$ tym obszarze dała możliwość zidentyfikowania luk badawczych $i$ możliwych dalszych kierunków badań dotyczacych wykorzystania tych narzędzi w projektowaniu procesów autonomicznych magazynów.
\end{abstract}

Słowa kluczowe: system wykrywania obiektów, bezpieczeństwo, wykrywanie człowieka, transport autonomiczny, magazyn, przegląd literatury 


\section{Introduction}

Recently, supply chains are facing an increasing logistics challenge, which is meeting the requirements and expectations of direct deliveries to the customer. At the same time, the development of tools in the area of Logistics 4.0, Industry 4.0, or the possibility of using Artificial Intelligence allows for the rapid development of warehouse systems [2]. This situation causes that automated guided vehicle (AGV) systems have become an integral part of overall logistic and manufacturing systems.

According to [1], an AGV is a driverless vehicle used for horizontal movement of materials. The main issues connected with its design and control are analyzed e.g. in [16]. The software aspects of AGVs are reviewed and summarized in [10]. Moreover, the AGVs classifications are summarized in work [11].

The use of AGVs in logistic systems gives the possibility to increase efficiency and flexibility of system operation or enhances collaborative operation. On the other side, their industrial application results in increased safety requirements and a well-defined organization of machine-human cooperation [18]. In order to ensure the safe performance of AGVs in their operational environment, one of the fundamental problems is connected with reliable human/other obstacle detection and proper introduction of emergency procedures.

The authors focus on analyzing human detection methods in the robot work area in terms of used parameters and used operational/reliability indicators, infrastructure necessary in the process of their implementation, type of used robot (service/industrial) and type of analyzed obstacle (static/dynamic).

Following this, the paper presents a systematic literature review on selected human detection systems. On the base of publications research, the authors analyze the number of publications on the subject, the main aspect in the context of which these systems were compared concerned the safety of robotic systems in the space of human occurrence, and the main advantages and drawbacks of the methods in various applications. The detailed analysis of the achievements in this area gives the possibility to identify research gaps and possible future research directions when using these tools in autonomous warehouses designing processes.

\section{Safety in autonomous transport systems - literature review}

In the known literature, there are a number of methods used to detect people/other obstacles that may occur on the robot path during the performance of an operational task. The selection of the most appropriate solution often depends on the type of process carried out by robots. Therefore, the purpose of the article is to conduct a preliminary comparative analysis of selected methods of human identification and detection used in the autonomous 
warehouse systems. The obtained results can be used as guidelines for designers and organizers of such technical systems.

In the context of the autonomous transport systems safety assurance, the main issue is the system's response to human presence/occurrence. For many years, robotic systems were designed assuming the separation of a robot and human operation. At the time of the emergence of the concept of sharing the working space by human and robot, it became necessary to develop new solutions and apply for the proper number and appropriate locations of technical equipment (cameras, scanners) to ensure the system safety, being understood as no occurrence of unacceptable risk [19] or a sense of absence of catastrophic loss (consequences) on the user(s) and the environment [10]. The main types of interactions between robot and human are presented in fig. 1.

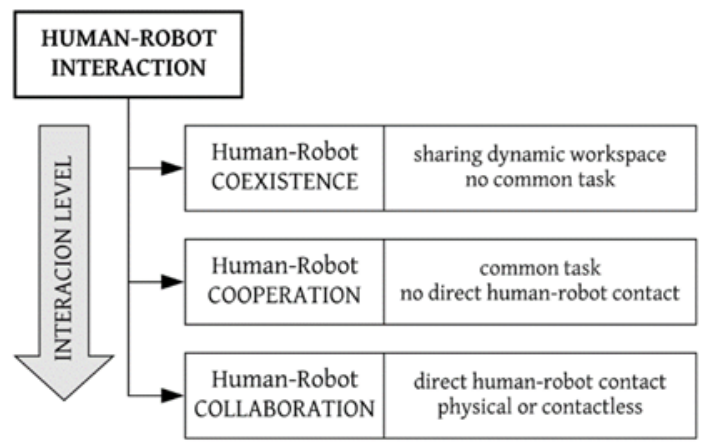

Fig. 1. Human-Robot Interaction types on the basis of interaction level [14]

The lowest level of interaction is limited only to sharing of space by a robot and a human. After increasing this level, common tasks appear, and at the highest level, there is direct contact between man and robot. Therefore, the higher the level of acceptable interaction in the system under consideration, the greater the requirements for the solutions used to ensure the safety of human beings in the close vicinity of the robot.

There can be found different classifications of the issues of AGVs safety in the known literature. For example, [12] provide a classification based on the methods used, including sensor type, safety function, and robot zone. Moreover, one can find the classifications based on the defined safety aspects such as motion control, planning, prediction, psychological factors (e.g. [15]), as well as design, pre-collision, and post-collision approaches and risk analysis (e.g. [14]).

Thus, the literature in the given research area can be divided into three main categories:

- a safe workplace for human assurance,

- anti-collision systems development,

- risk management.

In the given article the authors focus on the second problem, anti-collision systems development. This problem was chosen to be a subject of this paper due to its importance in designed robotic system, which authors are a part of as a project members. In connection 
to anti-collision systems, regardless of the available solutions, the basis for considering the safety of autonomous transport systems are the applicable safety standards.

\subsection{Safety standards}

The safety of AGVs bases on many regulations. The general overview of the most important documents for the standardization of mobile robot applications is presented in tab. 1.

Table 1

The overview of AGVs main standards, technical specifications (TS) and guidelines for mobile robot systems

\begin{tabular}{|l|l|}
\hline Standard no. & Standard title \\
\hline 2006/42/EG & Machinery directive \\
\hline EN 1525:1997 & $\begin{array}{l}\text { Safety of industrial trucks - Driverless trucks and their } \\
\text { systems }\end{array}$ \\
\hline ISO/IEC GUIDE 51:2014 & Safety aspects - Guidelines for their inclusion in standards \\
\hline ISO 10218-1:2011 & $\begin{array}{l}\text { Robots and robotic devices - Safety requirements for } \\
\text { industrial robots - Part 1: Robots }\end{array}$ \\
\hline ISO 10218-2:2011 & $\begin{array}{l}\text { Robots and robotic devices - Safety requirements for } \\
\text { industrial robots - Part 2: Robot systems and integration }\end{array}$ \\
\hline ISO 13849-1:2015 & $\begin{array}{l}\text { Safety of machinery - Safety-related parts of control } \\
\text { systems - Part 1: General principles for design }\end{array}$ \\
\hline ISO 13849-2:2012 & $\begin{array}{l}\text { Safety of machinery - Safety-related parts of control } \\
\text { systems - Part 2: Validation }\end{array}$ \\
\hline DIN EN 614-1:2009 & $\begin{array}{l}\text { Safety of machinery - Ergonomic design principles - Part 1: } \\
\text { Terminology and general principles }\end{array}$ \\
\hline DIN - VDI 2510 & Automated Guided Vehicle Systems (AGVS) \\
\hline VDI 2510-2: 2013 & $\begin{array}{l}\text { Automated Guided Vehicle Systems (AGVS) - Safety of } \\
\text { AGVS }\end{array}$ \\
\hline ISO/TS 15066:2016 & Robots and robotic devices - Collaborative robots \\
\hline ANSI/RIA R15.06-2012 & $\begin{array}{l}\text { Industrial Robots And Robot Systems - Safety } \\
\text { Requirements }\end{array}$ \\
\hline
\end{tabular}

The head of all documents is the Machinery Directive. It is mainly focused on ensuring an equal safety level for machines placed on the market or put into service in all European member states. According to this directive, machine must have at least one device for emergency stop. Emergency stop function is initiated by a single human action and it is used to reduce the effects of threat for people, machine itself or performed work.

Another international standard, EN 1525:1997 is the main standard concerning AGVs. However, its main disadvantages is connected with no harmonization with Machinery Directive and being out-of-date (does not include modern technologies being currently available). 
As supplementary standards, the international ISO standards should be fulfilled. They regard general or more detailed aspects, requirements and design principles of mobile robots. There can be found three groups of ISO standards for international machine safety:

- type A - general principles for design and safety aspects applicable for all machinery. There can be found a concept of working in reduced-risk conditions (e.g. reduced speed) based on reducing energy levels. However, none of regulations gives precise energy-limit values.

- type B - standards focused on one particular safety aspect (B1 standards) or focused on one type of safeguard (B2 standards). Among others there is a discussion about emergency stop function, design of safety-related parts of control systems and safety distances calculation. In ISO 13849-1, performance levels for safety functions are defined in terms of probability of dangerous failure per hour.

- type $\mathrm{C}$ - contains safety requirements for a particular machine or group of machines. For industrial robots ISO 10218-1 and ISO 10218-2 can be found. According to ISO 10218-1, industrial robots should have not only emergency stop function (as mentioned in Machinery Directive), but also protective stop function. This function can be triggered automatically unlike emergency stop function (only manual activation).

Moreover, the international standards developed by the World Trade Organization Technical Barriers to Trade (TBT) Committee also deserve special interest. These standards were developed in accordance with internationally recognized principles on standardization established in the Decision on Principles for the Development of International Standards, Guides, and Recommendations. Their main content is summarized in tab. 2.

Table 2

The overview of AGVs standards developed by TBT Committee

\begin{tabular}{|l|l|l|}
\hline \hline Standard no. & Standard title & Short description \\
\hline F3200-19 & $\begin{array}{l}\text { Standard Terminology for } \\
\text { Driverless Automatic Guided } \\
\text { Industrial Vehicles }\end{array}$ & $\begin{array}{l}\text { The scope of the standard includes } \\
\text { the terminology that covers terms } \\
\text { associated with unmanned, ground, } \\
\text { industrial vehicles. }\end{array}$ \\
\hline F3218-19 & $\begin{array}{l}\text { Standard Practice for Documenting } \\
\text { Environmental Conditions for } \\
\text { Utilization with A-UGV Test } \\
\text { Methods }\end{array}$ & $\begin{array}{l}\text { The standard is focused on the } \\
\text { investigation of the role of } \\
\text { environmental conditions during } \\
\text { the AGVs operation. The } \\
\text { environmental conditions are } \\
\text { classified into static, dynamic, or } \\
\text { transitional, or combinations } \\
\text { thereof. }\end{array}$ \\
\hline F3244-17 & $\begin{array}{l}\text { Standard Test Method for } \\
\text { Navigation: Defined Area }\end{array}$ & $\begin{array}{l}\text { method for evaluation if an AGV is } \\
\text { capable of travelling through a }\end{array}$ \\
\hline
\end{tabular}


tab. 2 cont.

\begin{tabular}{|l|l|l||}
\hline & & $\begin{array}{l}\text { defined space with limited } \\
\text { clearance. }\end{array}$ \\
\hline F3265-17 & $\begin{array}{l}\text { Standard Test Method for Grid- } \\
\text { Video Obstacle Measurement }\end{array}$ & $\begin{array}{l}\text { Test for measuring AGVs kinetic } \\
\text { energy reduction when objects } \\
\text { appear in the AGV path and } \\
\text { analysis of proper behavior of the } \\
\text { AGV (stop or avoiding the } \\
\text { obstacle). }\end{array}$ \\
\hline F3327-19 & $\begin{array}{l}\text { Standard Practice for Recording } \\
\text { the A-UGV Test Configuration }\end{array}$ & $\begin{array}{l}\text { The standard focused on a method } \\
\text { for recording of AGV hardware } \\
\text { and software control parameters. }\end{array}$ \\
\hline
\end{tabular}

In the context of anti-collision systems development, standards F3218-19 and F326517 should be discussed in detail. F3218-19 take into consideration environment conditions, which have significant influence on autonomous transport systems. Presented below, chosen environment conditions should be considered during system's tests:

- environmental consistency: static (similar environment throughout the test apparatus), dynamic (environment differs within the test apparatus e.g. change in temperature between repetitions) or transitional (different environment in different areas within the test apparatus),

- lighting: type of lighting (ambient or directed), source location of lighting and lighting level (five levels divided by amount of luxes),

- external emission: type of emitters, quantity of emitters and its location,

- temperature: five levels (from low below 0 degrees to extreme above 49 degrees),

- humidity: four levels (from low with less than 30\% to high for greater than $75 \%$ ),

- floor surface: coefficient of friction, known infrastructure being part of AGV map defined as five levels of grades (lowest with $0 \%-3 \%$ and highest with $16 \%$ and above).

Dynamic or transitional environmental require reporting for each unique set of environmental conditions. Lighting and emitters located outside AGV (from another AGV, in the environment) can affect optical sensor performance. Temperature can affect electronics, create condensation and reduce battery life. Humidity can cause increase in corrosion of metallic parts (when it is greater than 60\%) or rise in static electricity (when it is low). Ground surface conditions are connected with AGV traction, vibration, positioning and stability. All of this indicates the need to consider environmental conditions when conducting tests as part of the robot design process. One of these tests is described in standard F3265-17.

Standard F3265-17 has been developed for checking AGV operation in the case of objects appearing in the path and within the range of safety sensors. Under assumption that AGV stays on its path and an obstacle appears within the stop zone, the AGV will collide with the obstacle. Even within the stop zone, obstacle detection should cause slowing down. Due to this, kinetic energy reduction of $A G V$ is measured during this test. Taking into consideration distances between: 
- the location of the AGV at start time and the location of the A-UGV once the test piece enters the stop zone,

- the location of the A-UGV once the test piece enters the stop and the location of the AGV when it collides with the test piece,

- the location of the AGV where it collides with the test piece and the location of the AGV at stop time,

it can be confirmed that the energy is reduced by applying brakes or by other means. Presented test was developed for the situations when an object is falling from overhead or a pedestrian is stepping into the path at the last instant.

As summary of safety standards, it is worth mentioning that all of them gives general guidelines for safety assuring and it is impossible to give determined parameters (number and type of necessary sensors, speed etc.) applicable for all AGV. These parameters will vary significantly depending on the characteristics of the system under consideration. Therefore, when considering safety of robotic system during designing and testing, one should see the solutions available in the literature.

\subsection{Application of AGV safety issues based on the literature review}

Based on the carried out analyses of the available solutions in the literature in the area of AGVs safety for industrial and service applications, the authors propose own classifications with regard to the chosen criteria. The main authors' attention was focused on solutions used in obstacle detection, which is a basic element of pre-collision strategies.

The authors propose their own classification of the AGVs safety solutions available in the literature. The main classification criteria include used parameters and used operational/reliability indicators, infrastructure necessary in the process of their implementation, type of used robot (service/industrial) and type of detected obstacle (static/dynamic). According to the authors' knowledge, such classification of AGVs safety literature has not been earlier investigated. Moreover, the obtained results may be used for the development of a set of preliminary tips/aspects, necessary to be taken into account during the design process of systems based on autonomous mobile robot performance.

Thus, in tab. 3 , the summary of literature research is provided, highlighting the multifaceted aspect of this issue.

The following types of technical devices/sensors were used in the solutions distinguished in the Table 3, which are not being listed in it:

- 2D laser scanner,

- 3D scanner,

- 3D camera,

- 2D camera,

- TOF camera,

- Stereo camera,

- Fisheye camera,

- Ultrasonic scanner. 
In addition, the developed classification has taken into account the type of obstacle detected in the investigated solutions. In most cases, man is included in the group of dynamic obstacles, however, in some cases, he can also be perceived as a static obstacle. Therefore, it was necessary to consider solutions dedicated to both types of obstacles.

The classification of selected solutions shows the complexity of the problem of obstacle detection by the robot. The conducted research takes into account a wide range of aspects. The short case study that highlights the variety of possible solutions is presented in the next section.

Table 3

Summary of reviewed solutions in the aspect of AGV safety

\begin{tabular}{|c|c|c|}
\hline Parameter/Indicator & $\begin{array}{l}\text { Reference and obstacle type (SO - static } \\
\text { obstacle, DO - dynamic obstacle, SDO - } \\
\text { static and dynamic obstacles) }\end{array}$ & $\begin{array}{l}\text { Robot } \\
\text { type }\end{array}$ \\
\hline Braking distance & $\begin{array}{l}{[6]-\mathrm{SO}} \\
{[3]-\mathrm{DO}} \\
{[9]-\mathrm{SDO}}\end{array}$ & $\begin{array}{l}\text { Industrial } \\
\text { Industrial } \\
\text { Industrial }\end{array}$ \\
\hline Robot velocity & $\begin{array}{l}{[6]-\mathrm{SO}} \\
{[3]-\mathrm{DO}} \\
{[9]-\mathrm{SDO}} \\
{[22]-\mathrm{SDO}} \\
{[7]-\mathrm{SDO}} \\
{[17]-\mathrm{DO}} \\
{[25]-\mathrm{DO}}\end{array}$ & $\begin{array}{l}\text { Industrial } \\
\text { Industrial } \\
\text { Industrial } \\
\text { Industrial } \\
\text { Industrial } \\
\text { Service } \\
\text { Service } \\
\end{array}$ \\
\hline Obstacle velocity & $\begin{array}{l}{[9]-\text { SDO }} \\
{[22]-\text { SDO }} \\
{[26]-\text { SDO }} \\
{[17]-\text { DO }}\end{array}$ & $\begin{array}{l}\text { Industrial } \\
\text { Industrial } \\
\text { Industrial } \\
\text { Service } \\
\end{array}$ \\
\hline $\begin{array}{l}\text { Inaccuracy in obstacle localization } \\
\text { error }\end{array}$ & $\begin{array}{l}{[3]-\mathrm{SO}} \\
{[9]-\mathrm{SDO}} \\
{[7]-\mathrm{SDO}}\end{array}$ & $\begin{array}{l}\text { Industrial } \\
\text { Industrial } \\
\text { Industrial }\end{array}$ \\
\hline Light intensity & $\begin{array}{l}{[5]-\mathrm{SO}} \\
{[3]-\mathrm{SO}} \\
{[13]-\mathrm{SO}}\end{array}$ & $\begin{array}{l}\text { Industrial } \\
\text { Industrial } \\
\text { Industrial }\end{array}$ \\
\hline Processing time & [3] - SO & Industrial \\
\hline Expected location of the collision & [22] - SDO & Industrial \\
\hline Obstacle route relative to robot route & $\begin{array}{l}{[9]-\text { SDO }} \\
{[22]-\text { SDO }} \\
{[17]-\text { DO }} \\
{[25]-\text { DO }}\end{array}$ & $\begin{array}{l}\text { Industrial } \\
\text { Industrial } \\
\text { Service } \\
\text { Service } \\
\end{array}$ \\
\hline $\begin{array}{l}\text { Robot's knowledge about existing } \\
\text { obstacles }\end{array}$ & $\begin{array}{l}{[4]-\mathrm{SO}} \\
{[8]-\mathrm{SO}} \\
{[23]-\mathrm{SDO}} \\
\end{array}$ & $\begin{array}{l}\text { Industrial } \\
\text { Industrial } \\
\text { Industrial } \\
\end{array}$ \\
\hline
\end{tabular}


tab. 3 cont.

\begin{tabular}{|l|l|l|}
\hline & {$[20]-$ SO } & Industrial \\
\hline Tracking rate & {$[26]-$ SDO } & Industrial \\
& {$[24]-$ SDO } & Industrial \\
\hline Detection rate & {$[5]-$ SO } & Industrial \\
& {$[8]-$ SO } & Industrial \\
& {$[26]-$ SDO } & Industrial \\
& {$[24]-$ SDO } & Industrial \\
& {$[13]-$ SO } & Industrial \\
\hline Width of available space on the route & {$[20]-$ SO } & Industrial \\
in relation to vehicle width & & \\
\hline Estimated obstacle velocity error & {$[26]-$ SDO } & Industrial \\
& {$[17]-$ DO } & Service \\
\hline Sensitivity and specificity of obstacle & {$[4]-$ SO } & Industrial \\
detection test & {$[24]-$ SDO } & Industrial \\
\hline Distance between robot and obstacle & {$[6]-$ DO } & Industrial \\
\hline
\end{tabular}

In addition, despite meeting safety standards, unforeseen problems may arise due to the specific characteristics of different systems. Some of these problems, along with examples, are summarized in tab. 4.

Table 4

Examples of problems connected with obstacles detection

\begin{tabular}{|l|l|l||}
\hline Problem type & An example & Reference \\
\hline $\begin{array}{l}\text { Changing the ranges of } \\
\text { scanner zones }\end{array}$ & $\begin{array}{l}\text { Minimizing the ranges of scanner } \\
\text { zones when robot is near ramp }\end{array}$ & {$[27]$} \\
\hline $\begin{array}{l}\text { Impact of obstacle trajectory } \\
\text { on its detection speed }\end{array}$ & $\begin{array}{l}\text { Faster detection of obstacles } \\
\text { moving from the front of the robot }\end{array}$ & {$[6]$} \\
\hline Highly reflective surfaces & $\begin{array}{l}\text { High error in detecting obstacle } \\
\text { location when its surface is highly } \\
\text { reflective }\end{array}$ & {$[13]$} \\
\hline Shape and color of obstacles & $\begin{array}{l}\text { Problems with black obstacles } \\
\text { detection }\end{array}$ & {$[13]$} \\
\hline Obstacle surface structure & $\begin{array}{l}\text { Delayed obstacle detection when its } \\
\text { surface has many holes }\end{array}$ & {$[21]$} \\
\hline
\end{tabular}

The problems indicated in tab. 4 have a significant impact on human safety assurance. Failure to take them into account during the designing phase of a system of which AGVs is one of the operational elements may lead to undesirable events resulting in a threat to human safety. 


\section{Case study}

In 2.2, different solutions based on literature review in the aspect of AGV safety were presented. As a case study, safety solutions used in chosen mobile robot will be described.

The mobile robot designed for pallet transport in industrial spaces had been used for the analysis (fig. 2).

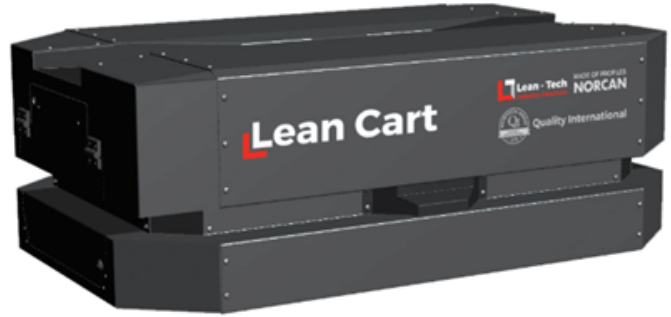

Fig. 2. Visualization of the robot used in case study

The main tasks of the robot include the identification of the pallet unit placed on the platform, autonomous joint of the platform and the transport of the load (up to $1500 \mathrm{~kg}$ of the evenly distributed load) to the indicated location. Analyzed safety solutions are divided into post- and pre-collision strategies, which are two groups of control methods for improving safety.

\subsection{Post-collision strategy}

The post-collision strategy includes designed features aimed at reducing the impact of the potential collision when unexpected (pedestrian is stepping into the path at the last instant) or unpreventable (e.g. maintenance actions) contact occurs [15]. The human safety is assured by limiting the maximum energy of the impact thanks to the robot structure [14].

The base features implemented according to post-collision strategy include:

- reduction of the unit weight to $200 \mathrm{~kg}$ - with the aluminum usage as the base of supporting structure and usage of the steel as the casing,

- elimination of the sharp edges and corners,

- equipping the robot with the low suspension preventing from hovering over man's foot.

Listed above features are the result of the identified mechanical hazards being part of risk assessment (possible cutting, crushing of human's body part).

The robot has two emergency stop buttons, which are secured against being switched on accidentally by the requirement of the confirmation with the additional button. They provide a low-level emergency braking system.

The robot has implemented additional systems to help man to detect the robot location as well as identify its current state. 
The robot's headlights (BLUE/RED spots) are the same as the ones used in forklifts. The moving robot illuminates the road in front of it, which enables operator to detect it easily even in the case of turns on the way. LED illumination installed on the robot informs about its state. Each color of the illumination stands for the specific state:

- Red - the robot is locked,

- Orange - the robot is going to make a turn. Orange illumination comes on the one side only indicating the turn side,

- Blue - the robot is moving,

- Pulsating blue - the robot is picking up or leaving the platform,

- Pulsating red - the robot came into the obstacle and waits for its removal.

The loudspeakers are the part of the robot's equipment enabling to inform about its state with the sound signals.

\subsection{Pre-collision strategy}

The pre-collision strategy covers techniques intended to ensure safety by monitoring the human, the robot, or both and modifying robot parameters before collision occurs [15]. This strategy includes mainly usage of the sensors to detect the obstacles and avoid collisions [14]. In the analyzed case, the sensors system is based on two 2D scanners. Each of them has the scanning angle of 270 degrees. They are placed diagonally on the robot in a way that gives 360 degrees view of the space around. Additionally, they enable controlling the stop zones and obstacle detection zones (fig. 3). If object is detected in the stop zone (which can be set to the maximum of 2 meters), the robot stops. If object is detected in the detection zone (which can be set to the maximum of 8 meters), the robot reduces its velocity. Scanners are placed at the height of $125 \mathrm{~mm}$. Due to this, human legs can be detected.

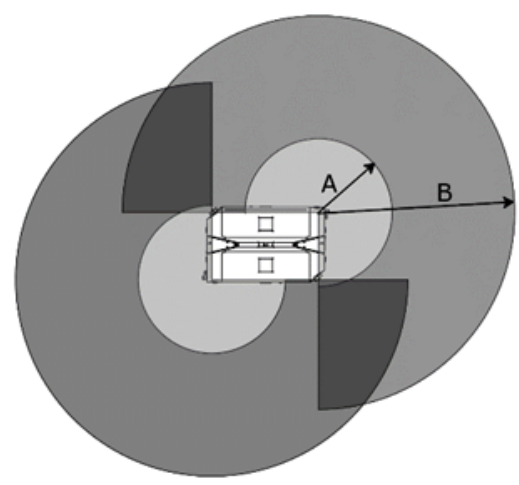

Fig. 3. Scheme presenting the scope of the zones controlled by the $2 \mathrm{D}$ laser scanners. Zone A may be changed easily up to 2 meters; zone B may be changed easily up to 8 meters 
Used scanners are optical sensors that scans its environment in two dimensions with infrared laser beams. They operate in accordance with o the time-of-flight measurement principle. They emit very short light pulses. If the light strikes an object, the object reflects the light which is then received by scanners. The distance to the object is calculated based on the time interval between the moment of transmission and moment of receipt. Additionally, scanners emit the light pulses with an angular resolution of 0.5 degree. This enables resolutions between $30 \mathrm{~mm}$ and $150 \mathrm{~mm}$.

Moreover, 3D cameras are installed on the robot at the height of $375 \mathrm{~mm}$ with the detection angle $69^{\circ} \times 56^{\circ}$ in the center of the robot's front and back. They provide additional support in detecting the obstacles along the way (placed above 2D laser scanner detection field) and they are used for detecting the platform, on which the load is placed. Implemented cameras operate according to the 3D time-of-flight measurement principle. To capture an image, the time-of-flight of a light signal between the camera and the object is measured for each pixel. Thousands of captured pixels deliver a detailed threedimensional distance image of the image area.

\section{Conclusion}

A growing interest in using robots, which are allowed to work in common space with humans, leads to the need to develop new standards and solutions. The purpose of this action is to increase the level of autonomous transport systems' safety. The new challenge is not only to protect people from collisions injuries but also to ensure their mental comfort during interactions with robots, as well as not to limit natural abilities and not reduce productivity and quality of work.

In this article, the review of selected solutions used in the aspect of warehouse autonomous transport systems safety was presented. Applicable standards connected with robot operation and solutions in the aspect of human detection preventing collision were shown.

As a case study, human safety solutions applied in a selected autonomous mobile robot used in a chosen warehouse were described. They were divided into pre-collision strategy and post-collision strategy.

This article is an introduction to the development of detailed guidelines for designers of an internal transport system based on autonomous mobile robots in the aspect of reducing the risk of adverse events for the proposed system solutions.

\section{Acknowledgement}

This work has been financed under the Research Project Robotic system of intelligent internal transport, co-financed by the European Union from the European Regional Development Fund within the framework of the Intelligent Development Operational Programme 2014-2020 within the framework of Measure POIR.04.01.00: Scientific research and development works Sub-measure POIR.04.01.04: Application projects. 


\section{References}

1. Aized T.: Modelling and performance maximization of an integrated automated guided vehicle system using coloured Petri net and response surface methods. Computers and Industrial Engineering, 2009, 57(3):822-831. DOI 10.1016/j.cie.2009.02.009.

2. Bechtsis D., Tsolakis N., Vlachos D., Iakovou E.: Sustainable supply chain management in the digitalisation era: The impact of Automated Guided Vehicles. Journal of Cleaner Production, 2017, 142. DOI 10.1016/j.jclepro.2016.10.057.

3. Bertozzi M., Bombini L., Broggi A., Coati A.: A Smart vision system for advanced LGV navigation and obstacle detection. IEEE Conference on Intelligent Transportation Systems, Proceedings, ITSC, 2012:508-513. DOI 10.1109/ITSC.2012.6338760.

4. Bostelman R., Hong T., Madhavan R.: Towards AGV safety and navigation advancement - Obstacle detection using a TOF range camera. 2005 International Conference on Advanced Robotics, ICAR '05, Proceedings, 2005, 2005:460-467. DOI 10.1109/ICAR.2005.1507450.

5. Bostelman R., Hongm T.: Safety standard advancement toward mobile robot use near humans. Proc . of Intl. Conf. on safety of industrial automated systems, 2005, (January 2015):1-8.http://www.et.byu.edu/ ered/ME486/Professional_Jounal.pdfAccessed.

6. Bostelman R., Shackleford W., Cheok G.: Safe Control of Manufacturing Vehicles Research Towards Standard Test Methods. 2012.

7. Bostelman R.B., Hong T.H., Messina E.: Intelligence level performance standards research for autonomous Vehicles. CEUR Workshop Proceedings, 2015, 1484, January 2015.

8. Bostelman R., Shackleford W.: Performance measurements towards improved manufacturing vehicle safety. 2009:289, DOI 10.1145/1865909.1865967.

9. Bostelman R., Shackleford W., Cheok G., Norcross R.: Standard test procedures and metrics development for automated guided vehicle safety standards. Performance Metrics for Intelligent Systems (PerMIS) Workshop, 2012, DOI 10.1145/ 2393091.2393123.

10. 10. Bozhinoski D., Di Ruscio D., Malavolta I., Pelliccione P., Crnkovic I.: Safety for mobile robotic system: A systematic mapping study from a software engineering perspective. Journal of Systems and Software, 2019, 151(2019):150-179. DOI 10.1016/j.jss.2019.02.021.

11. 11. Culler D., Long J.: A Prototype Smart Materials Warehouse Application Implemented Using Custom Mobile Robots and Open Source Vision Technology Developed Using EmguCV. Procedia Manufacturing, 2016, 5:1092-1106. DOI 10.1016/j.promfg.2016.08.080.

12. Halme R.J., Lanz M., Kämäräinen J., Pieters R., Latokartano J., Hietanen A.: Review of vision-based safety systems for human-robot collaboration. Procedia CIRP, 2018, 72:111-116, DOI 10.1016/j.procir.2018.03.043. 
13. Hedenberg K., Åstrand B.: 3D Sensors on Driverless Trucks for Detection of Overhanging Objects in the Pathway. Autonomous Industrial Vehicles: From the Laboratory to the Factory Floor, 2016:41-56. DOI 10.1520/stp159420150051.

14. Hentout A., Aouache M., Maoudj A., Akli I.: Human-robot interaction in industrial collaborative robotics: a literature review of the decade 2008-2017. Advanced Robotics, 2019, 33(15-16):764-799. DOI 10.1080/01691864.2019.1636714.

15. Lasota P.A., Fong T., Shah J.A.: A Survey of Methods for Safe Human-Robot Interaction. Foundations and Trends in Robotics, 2017, 5(3):261-349. DOI $10.1561 / 2300000052$.

16. Le-Anh T., De Koster M.B.M.: A review of design and control of automated guided vehicle systems. European Journal of Operational Research, 2006, 171(1):1-23. DOI 10.1016/j.ejor.2005.01.036.

17. Liu S.B., Roehm H., Heinzemann C., Lutkebohle I., Oehlerking J., Althoff M.: Provably safe motion of mobile robots in human environments. IEEE International Conference on Intelligent Robots and Systems, 2017, 2017-Septe:1351-1357. DOI 10.1109/IROS.2017.8202313.

18. Markis A., Papa M., Kaselautzke D., Rathmair M., Sattinger V., Brandstötter M.: Safety of Mobile Robot Systems in Industrial Applications. Proceedings of the ARW \& OAGM Workshop, 2019:26-31. DOI 10.3217/978-3-85125-663-5-04.

19. Missala T.: Safety integrity of turn-wrist robot constructions (in Polish). Tchoń, K. (ed). Robotics Advances, Robot systems and collaboration. Transport and Communication Publishers, 2006:139-148.

20. Norton A., Gavriel P., Yanco H.: A Standard Test Method for Evaluating Navigation and Obstacle Avoidance Capabilities of AGVs and AMRs. Smart and Sustainable Manufacturing Systems, 2019, 3(2):20190028. DOI 10.1520/ssms20190028.

21. Norton A., Yanco H.: Preliminary Development of a Test Method for Obstacle Detection and Avoidance in Industrial Environments. Autonomous Industrial Vehicles: From the Laboratory to the Factory Floor, 2016:23-40. DOI 10.1520/stp159420150059.

22. Pratama P.S., Kwun Jeong S., Sil Park S., Bong Kim S.: Moving Object Tracking and Avoidance Algorithm for Differential Driving AGV Based on Laser Measurement Technology. International Journal of Science and Engineering, 2012, 4(1):11-15. DOI 10.12777/ijse.4.1.11-15.

23. Sabattini L., Cardarelli E., Digani V., Secchi C., Fantuzzi C., Fuerstenberg K.: Advanced sensing and control techniques for multi AGV systems in shared industrial environments. IEEE International Conference on Emerging Technologies and Factory Automation, ETFA, 2015, 2015-Octob:1-7. DOI 10.1109/ETFA.2015.7301488.

24. Shneier M.O., Hong T., Cheok G., Saidi K., Shackleford W.: Performance Evaluation Methods for Human Detection and Tracking Systems for Robotic Applications. 2014. DOI 10.6028/NIST.IR.8045.

25. Tanha S.D.N., Dehkordi S.F., Korayem A.H.: Control a mobile robot in Social environments by considering human as a moving obstacle. Proceedings of the 6th RSI 
International Conference on Robotics and Mechatronics, IcRoM 2018, 2019, (IcRoM):256-260. DOI 10.1109/ICRoM.2018.8657641.

26. Vatavu A., Costea A.D., Nedevschi S.: Modeling and tracking of dynamic obstacles for logistic plants using omnidirectional stereo vision. IEEE International Conference on Intelligent Robots and Systems, 2015, 2015-Decem:3552-3558. DOI 10.1109/IROS.2015.7353873.

27. Yoon S., Bostelman R.: Analysis of Automatic through Autonomous - Unmanned Ground Vehicles (A-UGVs) towards Performance Standards. IEEE International Symposium on Robotic and Sensors Environments, ROSE 2019 - Proceedings, 2019. DOI 10.1109/ROSE.2019.8790421. 